\title{
Thiazolidinedione Antidiabetic Agent
}

National Cancer Institute

\section{Source}

National Cancer Institute. Thiazolidinedione Antidiabetic Agent. NCI Thesaurus. Code C98241.

Any antidiabetic agent with the glitazone (thiazolidinedione) base structure with antihyperglycemic activity. Glitazone antidiabetic agents selectively bind to and stimulate the nuclear receptor peroxisome proliferator-activated receptor (PPAR) gamma. This results in the selective transcription of a number of insulin-sensitive genes involved in glucose metabolism. This eventually enhances insulin sensitivity, reduces insulin resistance and decreases hepatic gluconeogenesis. PPARs function as transcription factors that regulate expressions of genes involved in cellular differentiation, development, and metabolism (carbohydrate, lipid, protein), as well as tumorigenesis; PPARgamma is expressed at high levels in adipose tissue. 